\title{
Parasitoids collected in the Caatinga biome in Brazil
}

\begin{abstract}
The Caatinga is the only biome restricted to the Brazilian territory, occupying basically the Region Northeast, with some areas in the state of Minas Gerais. Caatinga vegetation does not have green exuberance rainforests and the dry aspect of the physiognomies dominated by cacti and shrubs suggests low diversification of fauna and flora. To unravel your wealth you need a look more attentive, more open. So she reveals her great biodiversity, its biological relevance and its peculiar beauty. This study aimed to make a bibliographic summary of parasitoids of Caatinga, as well as their characteristics, main groups and species and studies performed.
\end{abstract}

Volume 6 Issue 2 - 2021

\author{
Carlos Henrique Marchiori \\ Biological Sciences, Instituto Federal Goiano, Brazil
}

Correspondence: Carlos Henrique Marchiori, Biological Sciences, Parasitology, Instituto Federal Goiano, Goiânia, Goiás, Brazil, Email chmarchiori@yahoo.com.br

Received: February 08, 2020 | Published: April 15, 202 I

Keywords: diptera, hymenoptera, biodiverside, fruit flies, region northeast

\section{Definition Caatinga}

The Caatinga (Figure 1) is the only biome restricted to the Brazilian territory, occupying basically the Region Northeast, with some areas in the state of Minas Gerais. Caatinga vegetation does not have green exuberance rainforests and the dry aspect of the physiognomies dominated by cacti and shrubs suggests low diversification of fauna and flora. To unravel your wealth you need a look more attentive, more open. So she reveals her great biodiversity, its biological relevance and its peculiar beauty. ${ }^{1}$

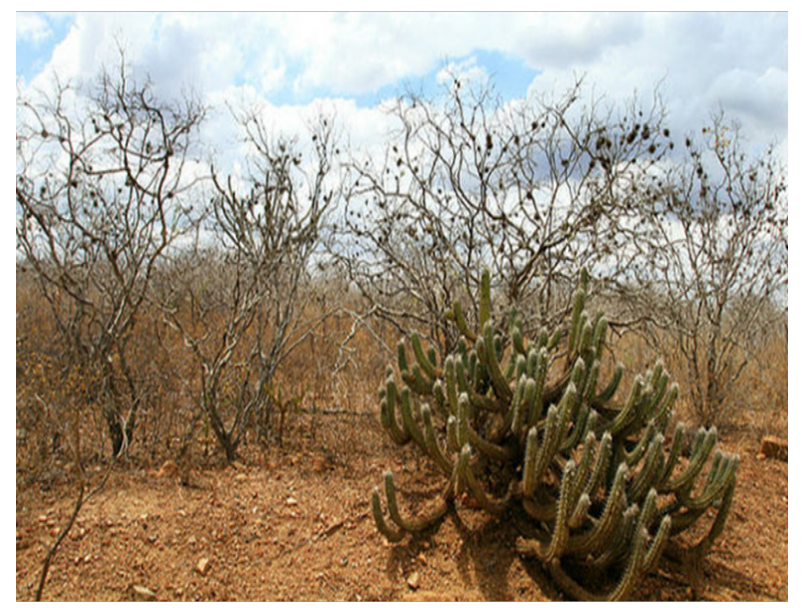

Figure I Caatinga biome.

\section{Characteristics hymenoptera}

Hymenoptera is one of the most numerous and diverse insect groups in existence. They are classified as "megadiverse" along with Lepidoptera, Diptera and Coleoptera. Hymenoptera includes over 115,000 described species and it is estimated that there are between 600,000 and 1.2 million of species. For the Neotropical region, 21 superfamilies, 76 families, 2,520 genera and about 24,000 species are recognized. It is estimated that the number of species reaches the figure of 80 thousand. Parasitoid hymenopterans are economically important, and some of their species are successfully used in biological control programs. ${ }^{2}$

\section{Characteristics parasitica hymenoptera}

Parasitica Hymenoptera represent the richest group of Hymenoptera and insect species; are common and abundant in all terrestrial ecosystems; develop as parasitoids of many insects, playing an important role in regulating pest populations and also phytophage insects, as they can lay their eggs on or directly within their host (egg, larva, pupa or imago) which is always dead due to the development of the larva that feeds on it. The large number of Parasitica Hymenoptera combined with their ability to respond to the density of the populations of its hosts makes them essential to maintain ecological balance and a force that contributes to the diversity of other organisms. ${ }^{3}$

\section{Main superfamilies and families}

Fernandes et al. ${ }^{4}$ conducted a survey of the fauna of the Hymenoptera families in an area of Caatinga in Mossoró, state of Rio Grande do Norte, Brazil collected a total of 5,057 Hymenoptera, belonging to 12 superfamilies and 36 families. The most abundant superfamilies were: Chalcidoidea $(1,206 / 23) 85 \%$ of the total), Vespoidea (886/17) $52 \%$, Ichneumonoidea (837/16) 55\%) and Platygastroidea (801/15) 84\%. and the most abundant families were: Platygastridae (801/15.84\%), Braconidae (616/12.18\%), Pteromalidae (583/11) 53\%, Figitidae (454/8) 98\%, Pompilidae (444/8) 78\% and Formicidae (predator) (268/5) 30\%.The data obtained allow us to affirm that the Caatinga encompasses substantial family richness of Hymenoptera and that renewed effort is necessary to sample its fauna in a more extensive way. ${ }^{5}$

\section{Important species}

The total number of samples was 198 fruit samples of Spondias spp. (cajá, umbu-cajá and umbu), we obtained 2,725 specimens of Anastrephae obliqua (Macquart) (Diptera: Tephritidae) parasitoids. Seven species of parasitoids belonging to the Braconidae, Figitidae (Eucoilinae) and Pteromalidae families were obtained. The braconids were the Opius bellus Gahan, Doryctobracon areolatus (Szépligeti), Utetes anastrephae (Viereck) and Asobara anastrephae (Muesebeck). The eucoilines were (acrescentar dois pontos) Aganaspis pelleranoi (Brèthes) and Dicerataspis flavipes (Kieffer), and P. vindemmiae (Rondani), belonging to the family Pteromalidae. Opius bellus was the most frequent parasitoid species with the highest parasitism rate in A. obliqua associated with Spondias spp. in the state of Piauí. The species of parasitoids $A$. anastrephae, D. Flavipes and $P$. vindemmiae are recorded for the first time in the state of Piauí.

\section{Studies carried out}

Ferreira $^{5}$ found in his study that the Superfamilies Chalcidoidea and were the most abundant Ichneumonoidea, which may be related 
to a greater availability of hosts for the representatives of these superfamilies. The superfamily Evanioidea was less abundant. Representatives were the families Braconidae and Ichneumonidae, Chalcididae. Ferreira ${ }^{5}$ concluded that this work constitutes the first study on the biodiversity of parasitic wasps to the entire massif of Baturiti, Bahia, Brazil. This region is considered of extreme importance for the conservation of biodiversity, according to data from the Ministry of the environment. ${ }^{5}$ The northeastern Brazil's semiarid climate offers favorable weather conditions for fruit production with proper irrigation techniques. Several counties in the region of Cariri, such as Crato, Barbalha, Santana do Cariri, and Missão Velha, located on the southern state of Ceará, where the semiarid climate prevails, have experienced expansion of guava orchards due to favorable climatic conditions and irrigation techniques. ${ }^{6}$

Fruit flies (Diptera: Tephritidae), Anastrepha spp. and Ceratitis capitata (Wiedemann), are important pests of Brazilian fruit-growing. In order to develop a system of pests integrated management in any region, it is essential to know the parasitoids (Hymenoptera) which can regulate the populations of these tefritids. ${ }^{7}$ Therefore was performed as study to know the diversity, geographic distribution and tritrophic relations of the himenopterous parasitoids of fruit flies, in Baixo Jaguaribe region, located in Ceará semiarid, Brazil. Four species of parasitoids were obtained: Doryctobracon areolatus (Szépligeti), Opius bellus Gahan, Utetes anastrephae (Viereck) (Braconidae) and (Eulophidae), Tetrastichus giffardianus Silvestri and the most frequently and with better geographical distribution in the region was D. areolatus. ${ }^{7}$

Doryctobracon areolatus was more common in association with species of Anastrepha - A. sororcula Zucchi, A. obliqua (Mcquart) and A. zenildae Zucchi, in native fruits and with C. capitata in exotic fruits. Tetrastichus giffardianus was obtained only in association with C. capitata in native and exotic fruits. This information can be used for inclusion of parasitoids in future integrated management programs of the fruit flies under the conditions of the Brazilian semiarid region.? According to Ferreira (2013) the study the variety of the flora and fauna of a region currently has been an indispensable process due to natural disasters and anthropogenic action which in recent times have decimated our biodiversity. Biodiversity involves all levels of natural variations, from the molecular, genetic level of existing species in the entire planet, so some anthropic actions have led to extinction, species not yet described by science.

In paper conducted with in fragments of caatinga, in the county of Jequié, Bahia, Brazil, with emphasis on the subfamilies of Braconidae (Ichneumonoidea) Alves ${ }^{8}$ collected 17,046 parasitoid hymenopterans were captured, identified and grouped into eight superfamilies and 30 families. The most frequent families were Braconidae (19.10\%), Platygastridae (15.60\%) and Bethylidae (13.35\%). A total of 3,251 braconids were identified as belonging to 20 subfamilies, of which the largest density was Microgastrinae, with $49.12 \%$ of individuals captured and followed by Doryctinae $(9.66 \%)$ and Orgilinae $(9.60 \%)$. For Alves (2003) this study expands the knowledge of the biodiversity of the caatinga parasitoid wasps providing subsidies for conservation programs of this biome.

This study was aimed to identify the parasitoids associated to fruit-fly species (Diptera: Tephritidae) occurring in an urban guava (Psidium guajava L.) (Myrtaceae) orchard located in Fortaleza, Ceará State, Brazil, as well as to determine the populational dynamics of these organisms in the ecosystem. Ripe and newly fallen guava fruits, from November 1999 to December 2000 were collected. The parasitoids obtained belong to the families Braconidae, Chalcididae, Figitidae (Eucoilinae), Diapriidae (Diapriinae) and Eulophidae. The most common parasitoids belong to the family Figitidae. ${ }^{9}$ For Araujo ${ }^{10}$ the objective of this paper was to know the species of the leafminer (Diptera: Agromyzidae) associated with melon plant Cucumis melo L., in the Chapada do Apodi, semi-arid region of the Rio Grande do Norte state, and report losses due to leafminer mining. This way, leaves infested with leafminer larvae were collected in the field and carried to laboratory, in order to obtain pupae. These pupae were placed inside glass containers until adults emergence. All identified adults belonged to Liriomyza trifolii (Burgess). In some farms leafminer caused losts that range from 10 to $15 \%$ of the whole area, due to low fruit ${ }^{\circ}$ brix value. From pupae also emerged some Opius sp. (Hymenoptera: Braconidae) individuals, a leafminer natural enemy, endoparasitoids the larva-pupae of $L$. trifolii.

\section{Conclusion}

Although still incipient, some surveys on fauna and flora have been carried out in this type of vegetation, but many have ignored insects, which can be considered the group with a great contribution to the essential processes of ecosystems. It is necessary to carry out more studies that focus on surveys of entomofauna in the Caatinga, since there is a notable lack of works of a similar nature, making it impossible even to make greater comparisons through bibliographies. For this reason, it is essential to make a greater effort to understand the prevalence of these insects, which are often ignored, despite their importance in maintaining ecological balance. ${ }^{11,12}$

\section{Acknowledgments}

None.

\section{Funding}

None.

\section{Conflicts of interest}

The authors declare that there is no conflict of interest.

\section{References}

1. Leal IR, Tabarelli M, Silva JC. Ecologia e conservação da caatinga. Recife Ed.tora da Universitária da UFPE. 2003:822.

2. Kogawa AC, Fernandes DRR, Lara RIR, et al. Fauna de Hymenoptera (Insecta) em área de caatinga na serra do Lima, Patu, RN, Brasil. Arquivos do Instituto Biológico. 2011;73(2):129-176.

3. La Salle J, Gauld ID. Parasitic Hymenoptera and biodiversity crisis. Redia. 1992;74:315-334.

4. Fernandes DRR, Guimarães JA, Araujo EL, et al. Survey of the Hymenoptera Fauna in a "Caatinga" Area in the State of Rio Grande do Norte, Northeastern Brazil. EntomoBrasilis. 2014;7(3):211-215.

5. Ferreira J PS. Diversidade de vespas parasitoides (Hymenoptera) coletadas em dois fragmentos de caatinga no município de Redenção, Ceara. Universidade da Integração Internacional da Lusofonia Afrobrasileira. 2016:34.

6. Azevedo FR, Guimarães JA, Simplício AAF, et al. Análise faunística e flutuação populacional de moscas-das-frutas (Diptera: Tephritidae) em pomares comerciais de goiaba na região do cariri cearense. Arquivos do Instituto Biológico. 2010;77(1):33-41.

7. Araujo EL, Fernandes EC, Silva RIR, et al. Parasitoides (Hymenoptera) de moscas-das-frutas (Diptera: Tephritidae) no semiárido do estado do Ceará, Brasil. Revista Brasileira de Fruticultura. 2015;37(3):610-616.

8. Alves FP. Parasitoides (insecta: Hymenoptera) em fragmentos de caatinga, com ênfase na família Braconidae (Ichneumonoidea. [Dissertação Mestrado] Universidade Estadual do Sudoeste da Bahia. 2013:77pp. 
9. Moura AP, Moura DCM. Levantamento e flutuação populacional de parasitoides de mosca-das-frutas (Diptera: Tephritidae) de ocorrência em goiabeira (Psidium guajava 1.) em Fortaleza, Ceará. Arquivo do Instituto Biológico. 2001;78(20):225-231.

10. Araujo E L. Occurrence of leafminer Liriomyza trifolii (Burgess) (Diptera: Agromyzidae), losts end its parasitoid, in Cucumis melo L., in the semiarid of the Rio Grande do Norte. Caatinga. 2007;20(3):210-212.
11. Oliveira IBR, Moura JZ, Moura Brito WC, et al. Diversidade da entomofauna em uma área de Caatinga no município de Bom Jesus-PI, Brasil. Cientifica. 2013;41(2):150-155.

12. Sousa EP S. Parasitoides de moscas-das-frutas (Diptera: Tephritidae) em Spondias spp. no estado do Piauí. 76 pp. Universidade Estadual do Maranhão. 2019. 